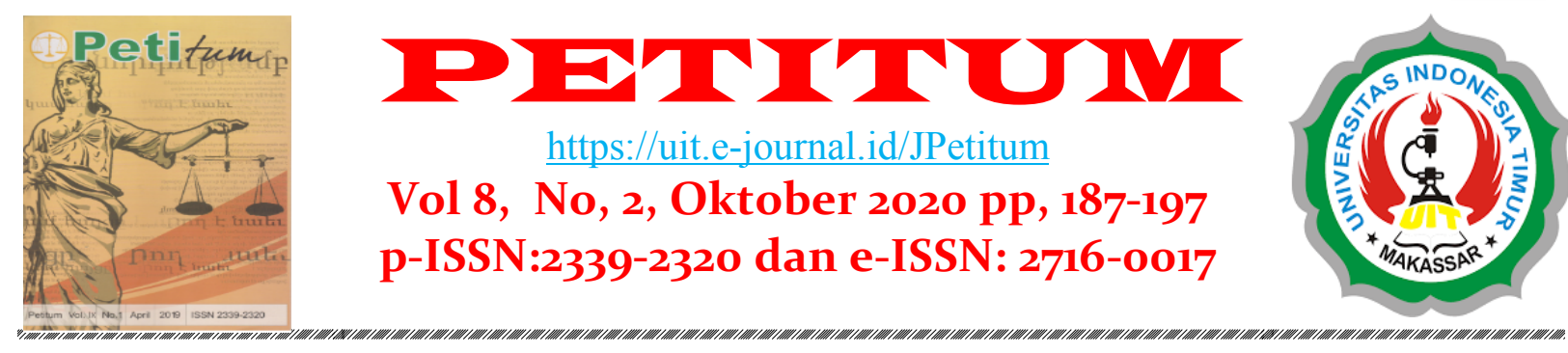

\title{
Penerapan Prinsip Kehati-Hatian Pembuatan Akta Otentik Pada Kantor Notaris Kabupaten Gowa
}

\section{Suhartati ${ }^{1}$}

IFakultas Hukum, Universitas Indonesia Timur, Email: suhartati.law@gmail.com

\begin{abstract}
Artikel info
Artikel history:

Received; 29-10-2020

Revised: 17-09-2020

Published: 29-10-2020

Keywords: Notary precautionary principle, legal consequences, fake letters.

ABSTRACT: This research aims to know and understand clearly the application of the precautionary principle of Notaries in making authentic deeds and the legal consequences of authentic deeds based on false letters and false statements. The research method used is empirical normative legal research, which is a combination of the normative legal approach with the addition of empirical elements. Data analysis in this study used qualitative analysis methods. From the results of the research, it was found that, first, the application of the precautionary principle by the notary in the process of making authentic deeds has been implemented but has not been implemented optimally because there are still often found authentic deeds based on false letters and false statements. Second, the legal consequences of notarial deeds based on false letters and false statements are null and void (nitiegbaarheid).
\end{abstract}

Kata Kunci: Prinsip Kehati-hatian Notaris, Akibat hukum, Surat Palsu.
ABSTRAK: Penelitian Ini Bertujuan Untuk Mengetahui dan
memahami secara jelas penerapan prinsip kehati-hatian Notaris
terhadap pembuatan akta Otentik dan akibat hukum terhadap akta
otentik yang berdasarkan surat palsu dan keterangan palsu. Metode
penelitian yang digunakan adalah penelitian hukum normatif empiris,
yang merupakan penggabungan Antara pendekatan hukum normatif
dengan adanya penambahan unsur-unsur empiris. Analisis data dalam
penelitian ini menggunakan metode analisis kualitatif. Dari Hasil
Penelitian ditemukan Bahwa, Pertama, Penerapan prinsip kehati-hatian
yang dilakukan oleh Notaris dalam proses pembuatan akta otentik itu
sudah diterapkan tetapi belum dilaksanakan secara optimal karena
masih sering dijumpai ada akta otentik yang dibuat berdasarkan surat
palsu dan keterangan palsu. Kedua, Akibat hukum terhadap akta notaris
yang dibuat berdasarkan surat palsu dan keterangan palsu adalah batal
demi hukum (nitiegbaarheid). Coresponden author:

Email: suhartati.law@gmail.com artikel dengan akses terbuka dibawah lisensi CC BY 


\section{PENDAHULUAN}

Di era modern pada saat ini perkembangan kejahatan dalam dunia hukum semakin berkembang karena adanya suatu tujuan dan niat yang tidak baik dari pihak-pihak tertentu. Kejahatan yang sering terjadi dalam profesi hukum salah satunya adalah dalam profesi Notaris. Notaris akhir-akhir ini sering dipermasalahkan karena akta otentik yang dibuatnya terindikasi mengandung unsur-unsur tindak pidana, hal ini disebabkan karena kurang kehati-hatian Notaris terhadap para pihak yang menghadap membuat akta otentik yang sering mengambil kesempatan demi keuntungannya sendiri dengan cara melakukan kejahatan seperti memberikan surat palsu dan keterangan palsu kedalam akta yang dibuat oleh Notaris (Manuaba, P., Bagus, I., Parsa, I. W., Ariawan, K., \& Gusti, I. 2018).

Terdapatnya permasalahan yang terjadi dalam proses pembuatan akta otentik disebabkan karena dalam Undang Undang Jabatan Notaris (UUJN) tidak mengatur secara jelas prinsip atau langkah-langkah Notaris untuk bekerja lebih berhati-hati dalam proses pembuatan akta, sehingga notaris tidak memiliki pedoman dan tuntunan yang berguna untuk mencegah terjadinya kejahatan dalam akta otentik yang dibuat oleh notaris. Kekaburan norma dalam Undang-Undang Republik Indonesia Jabatan Notaris undang-Undang Jabatan Notaris Perubahannya (UUJN-P) Nomor: 2 Tahun 2014 tersebut dapat dilihat dalam Pasal 16 ayat (1) huruf (a) disebutkan mengenai kewajiban Notaris yaitu dalam menjalankan jabatannya, Notaris wajib bertindak amanah, jujur, saksama, mandiri, tidak berpihak, dan menjaga kepentingan pihak yang terkait dalam perbuatan hukum Notaris dalam menjalankan tugas dan jabatannya dalam membuat akta tidak luput dari kesalahan atau kekeliruan baik yang disebabkan karena perilaku yang tidak profesional atau memihak salah satu pihak sehingga terjadi permasalahan dalam akta yang dibuatnya (Sodiq, M. 2016). Sebagai pejabat umum yang berwenang untuk membuat akta otentik, notaris seringkali bertindak tidak hati-hati yang berakibat menimbulkan permasalahan hukum, baik dalam ranah hukum pidana maupun ranah hukum perdata, ini disebabkan karena para pihak yang membuat akta otentik memberikan dokumen palsu ataupun memberikan keterangan palsu kepada Notaris sehingga menimbulkan permasalahan hukum terhadap akta otentik yang dibuatnya.

Hal ini menjadikan pertanyaan apakah Notaris telah bertindak tidak sesuai dengan Peraturan Perundang-Undangan dan Kode Etik Notaris ataukah ada kekeliruan baik disengaja ataupun tidak disengaja oleh para pihak atau salah satu pihak untuk berusaha melakukan kecurangan sehingga menimbulkan kerugian bagi pihak lain dengan memberikan keterangan dan dokumen-dokumen yang tidak benar. Dalam Undang-Undang Nomor 2 Tahun 2014 tentang perubahan atas Undang-Undang Nomor 30 Tahun 2004 tentang Jabatan Notaris diatur bahwa ketika Notaris dalam menjalankan tugas jabatannya telah melakukan pelanggaran yang menyebabkan penyimpangan dari hukum maka Notaris dapat dijatuhi sanksi yaitu berupa sanksi perdata, administratif atau Kode Etik Jabatan Notaris.

Akan tetapi seringkali Notaris membuat surat-surat berdasarkan keterangan yang dihadapkan oleh penghadap atau pihak yang menghendaki adanya surat atau akta otentik tersebut tanpa mengetahui kebenaran yang ada dilapangan atau bahkan Notaris keliru dalam mencantumkan keterangan yang diinginkan oleh penghadap. 
Undang-Undang jabatan Notaris tidak menyebutkan adanya penerapan sanksi pidana tetapi jika terbukti suatu tindakan hukum terhadap pelanggaran yang dilakukan oleh Notaris tersebut mengundang unsur-unsur pemalsuan atas kesengajaan atau kelalaian dalam pembuatan surat atau akta otentik yang keterangan isinya palsu maka setelah dijatuhi sanksi administratif/kode etik profesi jabatan Notaris dan sanksi keperdataan kemudian dapat ditarik dan dikualifikasikan sebagai suatu tindak pidana yang dilakukan oleh Notaris yang menerangkan adanya bukti keterlibatan secara sengaja melakukan kejahatan pemalsuan akta otentik. Apabila terbukti maka sudah menjadi kewajiban Notaris untuk mempertanggungjawabkan akta yang dibuat oleh atau di hadapannya yang menuai kesalahan tersebut. Undang Undang Jabatan Notaris hanya mencantumkan sanksi perdata dan administasi saja dimana sanksi ini dirasa kurang efektif bagi pihak-pihak yang merasa dirugikan.

Notaris sebagai pejabat umum yang menjalankan profesi dalam memberikan jasa hukum kepada masyarakat perlu mendapatkan perlindungan dan jaminan demi tercapainya kepastian hukum. Bentuk perlindungan jabatan Notaris agar nantinya Notaris dapat bertindak lebih berhati-hati dalam membuat akta otentik, penulis dapat memberikan masukan bahwa perlu diperjelas kembali tentang kewajiban Notaris untuk melakukan prinsip-prinsip kehati-hatian dalam proses pembuatan akta otentik agar nantinya akta yang dibuat tidak menimbulkan permasalahan hukum (Prabowo, T. S. 2017).

\section{METODE PENELITIAN}

Metode penelitian yang digunakan adalah pendekatan secara yuridis normatif dan yuridis empiris sebagai bahan pendukung dalam penelitian. Metode penelitian dengan menggunakan pendekatan yuridis normatif adalah metode penelitian yang dilakukan berdasarkan bahan hukum utama dengan cara menelaah teori-teori, konsep-konsep, asasasas hukum serta peraturan perundang-undangan yang berhubungan dengan penelitian ini, Pendekatan ini dikenal pula dengan pendekatan kepustakaan, yakni dengan mempelajari buku-buku, peraturan perundang-undangan dan dokumen lain yang berhubungan dengan penelitian ini. Metode penelitian dengan menggunakan pendekatan yuridis empiris adalah metode penelitian dengan mengkaji dan meneliti data sekunder terlebih dahulu yang kemudian dilanjutkan dengan data primer yang diperoleh dilapangan. Alasan menggunakan metode ini agar lebih mudah dalam menyajikan data secara langsung dengan menyajikan data yang diperoleh dari lapangan berdasarkan penelitian terhadap NotarisNotaris yang ada di Kabupaten Gowa sebagai sampel informan serta berdasarkan data-data yang diperoleh dari sumber-sumber pustaka yang terkait dengan permasalahan yang dikaji.

\section{HASIL PENELITIAN \& PEMBAHASAN}

\section{A. Penerapan Prinsip Kehati-hatian Notaris Dalam Proses Pembuatan Akta Otentik.}

Notaris dipandang sebagai seseorang figure yang keterangan-keterangannya dapat diandalkan dan dapat dipercayai yang tanda tangannya serta segel (capnya) memberi jaminan dan bukti kuat dalam akta otentik yang dibuatnya. Namun pada saat ini sering terjadi permasalahan hukum dalam pembuatan akta yang dibuat oleh notaris, karena akta yang dibuatnya terindikasi mengandung unsur-unsur pidana karena pihak-pihak 
yang menghadap dalam proses pembuatan akta memberikan dokumen-dokumen atau surat palsu serta mencantumkan keterangan palsu kedalam akta otentik yang dibuat notaris. Untuk mencegah notaris terjerat dalam permasalahan hukum, adapun bentukbentuk prinsip kehati-hatian yang dapat dilaksanakan Notaris MUHAMMAD MANSUR HANISE dalam proses pembuatan akta berdasarkan wawancara yang dilaksanakan pada hari senin tanggal 11-11-2019 (sebelas bulan November tahun dua ribu sembilan belas) meliputi:

1. Pengenalan Terhadap Identitas Penghadap.

Tugasnya notaris sebelum memulai membuat akta tentunya dihadapkan oleh para pihak yang ingin membuat akta otentik, tentunya notaris sebelum memasukan identitas para pihak kedalam suatu akta, notaris harus mengecek identitas pihak-pihak seperti KTP, KK, atau Passport serta mencocokan foto pemilik Identitas dengan pihakpihak yang membuat akta otentik, agar mencegah pemalsuan identitas terhadap akta yang dibuat notaris.

Prinsip kehati-hatian dalam hal melakukan pengenalan terhadap identitas penghadap yaitu dengan Cara Notaris lebih teliti dalam mempehatikan dokumen asli yang diperlihatkan, salah satunya adalah Kartu Tanda Penduduk (KTP), dimana Notaris mencocokkan foto yang ada dalam Kartu Tanda Penduduk (KTP) dengan para pihak yang menghadap, selain itu jika para pihak yang menghapap merupakan suami istri dan/atau obyek dalam akta merupakan harta satu kesatuan maka dokumen tambahan yang perlu diperlihatkan ialah Buku Nikah asli dan Kartu Keluarga (KK) asli.

Selain itu jika pada saat para pihak menghadap tidak dapat memperlihatkan dokumen asli tersebut di atas maka Notaris harus meminta kepada para pihak membuat Surat Keterangan Perekaman jika KTP (kartu Tanda Penduduk) dapat diperlihatkan, begitupun dengan dokumen lainnya.

Notaris juga Menanyakan dan mencocokan langsung kebenaran biodata, seperti tanggal dan alamat di dalam Kartu Tanda Penduduk kepada para penghadap. Cara tersebut merupakan salah satu cara untuk menerapkan prinsip kehati-hatian dalam pembuatan akta otentik. Jika yang menghadap bukan merupakan penghadap yang sesuai di dalam Kartu Tanda Penduduk, maka akan terlihat secara fisik dan perilaku yang dapat dilihat langsung ada kejanggalan dan perbedaan.

2. Memverifikasi data subyek dan obyek penghadap.

Maksud dan tujuan Memverifikasi adalah memeriksa data-data subyek dari para pihak apakah berwenang dan cakap atau tidak dalam melakukan perbuatan hukum sehingga dapat memenuhi syarat sahnya dari suatu akta seperti, apakah pihak yang bertindak sudah berumur minimal 18 Tahun atau telah menikah menurut Pasal 39 ayat 1 huruf a UUJNP.

Memverifikasi secara cermat data subyek dan obyek penghadap yaitu dengan cara Notaris lebih kritis dalam melihat data para pihak, salah satunya mengenai Usia para pihak sesuai pasal 39 ayat 1 huruf a UUJNP (Undang-Undang jabatan Notaris Perubahannya). Selain itu Notaris lebih teliti dalam memeriksa dokumen-dokumen obyek yang dibawa oleh penghadap contohnya memeriksa sertipikat tanah Ke Badan Pertanahan Nasional apakah sertifikat tersebut merupakan sertifikat asli atau palsu atau memang benar atau tidak yang bersangkutan (penghadap) yang memiliki 
sertifikat tersebut atau dokumen-dokumen lainnya yang ada kaitannya dengan maksud tujuan pembuatan akta tersebut.

3. Tenggang waktu dalam pengerjaan akta otentik

Agar menghasilkan akta yang baik sepatutnya notaris memberikan tenggang waktu dalam proses pembuatan akta agar tidak terburu-buru dan dapat bekerja secara cermat serta teliti sehingga tidak menimbulkan kesalahan dalam pengerjaan akta notaris.

Akta otentik, seperti kita ketahui isi akta otentik merupakan penjelasan mengenai hak dan kewajiban para pihak untuk mendapatkan kepastian hukum, sehingga dapa menimalisir suatu sengketa, sebab hal tersebutlah Notaris membutuhkan waktu dalam mengerjakan suatu akta sehingga tidak menimbulkan kesalahan pada penulisan akta dalam hal ini salah satunya yang dimaksud komparisi akta. Jika ada dalam komparisi akta maka kekuatan akta menjadi tidak otentisitas karena bertentangan dengan syarat dan ketentuan yang diberlakukan oleh Undang-Undang.

4. Bertindak hati-hati, cermat dan teliti.

Bertindak berhati-hati, cermat dan teliti dalam proses pembuatan akta kata-kata yang dituangkan ke dalam akta, karena dalam pelaksanaanya sangat sering terjadi akta yang dibuat notaris sering dipermasalahkan karena kata-kata yang dibuat tidak jelas atau menimbulkan penafsiran.

Untuk memenuhi unsur tersebut Notaris wajib memeriksa kata demi kata yang tertuang dalam akta untuk meminimalisir kesalahan dalam penulisan akta, karena pada asasnya apa yang tertuang didalam akta otentik haruslah benar, agar kekuatan akta otentik sebagai alat bukti dapat dipertahankan. Notaris dalam hal pembuatan akta otentik tidak boleh memihak pada salah satu masyarakat atau para pihak pengguna jasa dalam pembuatan akta otentik.

5. Memenuhi syarat.

Untuk membuat akta notariil yang jauh dari indikasi permasalahan hukum tentunya notaris harus memenuhi syarat formal dan syarat materil dari pembuatan akta notaris berdasarkan Undang-Undang Jabatan Notaris ketentuan mengenai syarat formal dalam pembuatan akta diatur dalam pasal 38 (Undang-Undang Jabatan Notaris Perbuahannya) UUJN-P, sedangkan syarat materil yang harus dipenuhi dalam pembuatan akta otentik diatur dalam pasal 1320 (Kitab Undang-Undang Hukum Perdata) KUH Perdata.

6. Penandatanganan dan pembubuhan jempol akta

Saat penandatanganan akta, Notaris terlebih dahulu menjelaskan apa isi akta tersebut, apabila sudah dibacakan, dan para penghadap sudah mengerti serta memahami akta tersebut maka para penghadap menandatangani akta otentik yang sudah dibuat serta membubuhkan sidik jari pada lembar tersendiri, tetapi satu kesatuan atas akta otentik tersebut.

Terhadap prinsip kehati-hatiaan Notaris MUHAMMAD MANSUR HANISE pada hari tanggal 19-11-2019 (sembilan belas bulan November tahun dua ribu sembilan belas), di mana ada seorang Klien membawa dokumen yaitu Akta Kuasa Menjual, sertipikat, PBB (Pajak Bumi dan Bangunan), Kartu Tanda Penduduk (KTP) penerima kuasa, surat 
keterangan kematian, yang meminta untuk dasar dibuatkannya Akta Jual Beli, Namun ditolak oleh Notaris tersebut dengan alasan bahwa salah satu dari para pihak tersebut sudah ada yang meninggal dunia, di mana apabila salah satu dari para pihak tersebut sudah meninggal dunia maka akta kuasa menjual tersebut berakhir dengan sendirinya yang sebagaimana di atur di dalam Pasal 1813 Kitab Undang-Undang hukum Perdata (KUHPer) salah satu sebab berakhirnya pemberian kuasa adalah dengan meninggalnya, pengampuannya, atau pailitnya si pemberi kuasa maupun si kuasa. Jadi, berdasarkan pasal tersebut jelas bahwa surat kuasa gugur atau berakhir ketika si pemberi kuasa ataupun si (penerima) kuasa meninggal dunia. Maka dari itu Notaris tersebut menyarankan untuk mencari Ahli Waris Pihak pertama dan meminta untuk membuatkan surat keterangan ahli waris.

\section{B. Akibat Hukum Akta Notaris Yang Dibuat Berdasarkan Surat Palsu Dan Keterangan Palsu.}

Adapun syarat-syarat kebatalan (nietieg) yang diatur dalam (Kitab Undang-Undang Hukum Perdata) KUHPerdata dapat dibagi menjadi dua, yaitu:

a. Dapat dibatalkan (Vernietigbaarheid).

1. Melanggar ketentuan Pasal 1230 ayat 1 KUHPerdata (sepakat mereka yang mengikat diri). Pasal 1320 ayat 1 KUHPerdata (Kitab Undang-Undang Hukum Perdata) menyatakan perjanjian adalah sah apabila diantara para pihak sepakat mengikatkan diri. Tiada sepakat yang sah (cacat kehendak/wilsgbrek). Dalam KUHPerdata (Kitab Undang-Undang Hukum Perdata) terdapat tiga hal yang menjadi pembatalan perjanjian berdasarkan cacat kehendak, yaitu Kekhilafan (Dwaling), Paksaan (Dwang) dan Penipuan (Bedrog).

2. Melanggar syarat subyektif sahnya perjanjian, yaitu melanggar Pasal 1320 ayat 2 KUHPerdata (Kitab Undang-Undang Hukum Perdata) (kecakapan membuat perjanjian). Melanggar Pasal 1320 ayat 2 KUHPerdata (Kitab Undang-Undang Hukum Perdata) (Cakap bertindak menurut hukum), pasal ini menentukan bahwa perjanjian adalah sah apabila para pihak cakap dalam membuat suatu perjanjian. Cakap yang dimaksud ialah:

1. Anak yang belum dewasa;

2. Orang yang ditaruh di bawah pengampunan;

3. Perempuan yang telah kawin dalam hal-hal yang ditentukan UndangUndang dan pada umumnya semua orang yang oleh Undang-Undang dilarang untuk membuat persetujuan tertentu.

b. Batal Demi Hukum (Neitigbaarheid) .

1. Melanggar ketentuan Pasal 1320 ayat 3 KUHPerdata (suatu hal tertentu). Suatu hal tertentu yang dimaksudkan adalah bahwa obyek perjanjian tersebut haruslah tertentu, dapat ditentukan yaitu suatu barang yang dapat diperdagangkan dan dapat dietentukan jenisnya secara jelas dan tidak kabur.

2. Melanggar ketentuan Pasal 1320 ayat 4 KUHPerdata (suatu sebab yang halal). Suatu sebab yang halal, apabila perjanjian itu dibuat berdasarkan kepada sebab yang sah dan dibenarkan oleh undang-undang dan tidak melanggar ketentuan-ketentuan tentang isi dari perjanjian. 
Suatu perjanjian yang tidak memenuhi syarat yang sah sebagaimana diatur dalam pasal 1320 KUHPerdata, baik syarat-syarat subyektif maupun obyektif akan mempunyai akibat-akibat sebagai berikut:

a. Apabila tidak ada kesepakatan maka tidak timbul perjanjian.

b. Dapat dibatalkan, apabila perjanjian tersebut lahir karena adanya cacat kehendak (wilsgebreke) atau karena ketidakcakapan (onbekwaamheid) Pasal 1320 syarat 1 dan 2, berarti hal ini terkait dengan syarat subyektif, sehingga berakibat kontrak itu dapat dibatalkan.

c. Batal demi hukum, apabila terdapat perjanjian yang tidak memenuhi syarat obyek tertentu atau tidak mempunyai kausa atau kausanya tidak diperbolehkan (Pasal 1320 ayat 2 dan 4), berarti hal ini terkait dengan unsur-unsur obyektifnya, sehingga berakibat perjanjian tersebut batal demi hukum

Dalam Pasal 84 UUJN-P tentang akibat hukum akta yang dibuat notaris batal demi hukum sudah dihapuskan. Namun dalam hukum positif yang berlaku, berdasarkan Pasal 1320 KUHPerdata apabila didalam suatu perjanjian tidak terpenuhinya syarat obyektif dalam pasal tersebut maka akibat perjanjian tersebut batal demi hukum. Selanjutnya dalam Pasal 1335 KUHPerdata ditegaskan bahwa, "Suatu perjanjian tanpa sebab, atau dibuat berdasarkan suatu sebab yang palsu atau yang terlarang, tidaklah mempunyai kekuatan”.

Sebab yang diperbolehkan maksudnya adalah apa yang hendak dicapai para pihak dalam perjanjian atau kontrak tersebut harus disertai etikat baik dan tidak bertentangan dengan peraturan perundangundangan, ketertiban umum, dan kesusilaan sesuai Pasal 1337 KUHPerdata. Apabila terjadi pemalsuan surat dan keterangan palsu yang diberikan oleh para pihak didalam proses pembuatan akta maka tanggungjawab materil merupakan tanggungjawab dari para pihak yang telah memberikan data palsu maupun keterangan palsu kehadapan notaris. Dan para pihak dapat dituntut dan bertanggungjawab atas Tindak Pidana Surat Palsu dan Keterangan Palsu sesuai Pasal 263, 264 dan Pasal 266 KUHP. Tugas notaris hanya menuangkan keinginan para pihak bukan memastikan kebenaran materil dari data yang dibawa oleh para pihak, sehingga dalam menjalankan tugasnya notaris harus menerapkan prinsip kehati-hatian agar tidak percaya secepat mungkin terhadap pihak-pihak yang ingin membuat akta otentik. Dengan demikian berdasarkan hukum positif yang berlaku apabila suatu akta yang dibuat notaris mengandung unsur-unsur tindak pidana surat palsu dan keterangan palsu oleh para pihak, maka jelas-jelas perbuatan tersebut melanggar Pasal 263, 264 dan 266 KUHP, sehingga sesuai Pasal 1320 (Kitab UndangUndang hukum Perdata) KUHPerdata ayat (4), akibat hukum perjanjian dalam isi akta otentik tersebut adalah batal demi hukum atau batal sejak perjanjian tersebut dibuat (nitiegbaarheid) dan akta yang dibuat oleh notaris tersebut menjadi terdegradasi nilai kekuatan pembuktiannya dari akta otentik menjadi akta dibawah tangan akan tetapi tentang kebenaran formal yang terdapat dalam kepala dan penutup akta tetap mengikat para pihak yang membuatnya.

Notaris MUHAMMAD MANSUR HANISE, pada hari selasa tanggal 26-11-2019 (dua puluh enam bulan November tahun dua ribu sembilan belas) mengatakan bahwa akibat hukum terhapap akta otentik yang dibuat oleh notaris yang berdasarkan surat palsu atau keterangan palsu yaitu harus dilihat dari perbuatan hukumnya terlebih 
dahulu, Kesalahan datang dari penghadap seperti pemalsuan dokumen dan yang hadir bukan penghadap sesungguhnya, Notaris tidak bertanggung jawab untuk hal itu. Hal tersebut merupakan tanggung jawab dari pihak penghadap sendiri. Notaris tidak ada kewajiban untuk menyelidiki secara materil apa-apa (hal-hal) yang dikemukakan pada penghadap. Sedangkan terhadap aktanya dapat didegradasi menjadi akta dibawah tangan. Dan pada dasarnya akta itu dibuat atas kehendak para pihak, dan sebelum para pihak menandatangani akta tersebut Notaris terlebih dahulu membacakan, menjelaskan akta tersebut dihadapan para pihak.

Tetapi menurut Notaris MUHAMMAD MANSUR HANISE dalam pembuatan akta Jika suatu kesalahan yang dilakukan oleh Notaris dapat dibuktikan, maka Notaris itu dapat juga dikenakan sanksi berupa ancaman sebagaimana yang telah ditentukan oleh undang-undang. Sebagaimana yang dimaksud dalam Pasal 84 UUJN yang menetapkan bahwa "dapat menjadi alasan bagi pihak yang menderita kerugian untuk menuntut penggantian biaya, ganti rugi dan bunga kepada Notaris".

Ganti rugi atas dasar perbuatan melanggar hukum di dalam hukum perdata diatur dalam Pasal 1365 KUH Perdata, yang menentukan:

“Tiap perbuatan melanggar hukum yang membawa kerugian kepada orang lain, mewajibkan orang yang karena salahnya menerbitkan kerugian itu, menggantikan kerugian tersebut"

Apabila memperhatikan ketentuan Pasal 1365 KUH Perdata diatas, di dalamnya terkandung unsur-unsur sebagai berikut:

1. Perbuatan yang melanggar hukum;

2. Harus ada kesalahan;

3. Harus ada kerugian yang ditimbulkan;

4. Adanya hubungan kausal antara perbuatan dan kerugian.

Pasal 41 UU perubahan atas UUJN menentukan adanya sanksi perdata, jika Notaris melakukan perbuatan melawan hukum atau pelanggaran terhadap Pasal 38, Pasal 39, dan Pasal 40 UU perubahan atas UUJN maka akta Notaris hanya akan mempunyai pembuktian sebagai akta di bawah tangan. Akibat dari akta Notaris yang seperti itu, maka dapat menjadi alasan bagi pihak yang menderita kerugian untuk menuntut penggantian biaya, ganti rugi dan bunga kepada Notaris (Afifah, K. 2017).

Perihal kesalahan dalam perbuatan melanggar hukum, dalam hukum perdata tidak membedakan antara kesalahan yang ditimbulkan karena kesengajaan pelaku, melainkan juga karena kesalahan atau kurang hati-hatinya pelaku. Ketentuan ini sesuai dengan yang dikemukakan oleh Riduan Syahrani sebagai berikut: "tidak kurang hatihati”. Notaris yang membuat akta ternyata tidak sesuai dengan wewenangnya dapat terjadi karena kesengajaan maupun karena kelalaiannya, yang berarti telah salah sehingga unsur harus ada kesalahan telah terpenuhi.

Akibat hukum bagi notaris yang tidak mau menjalankan tanggungjawab perdatanya untuk mengganti kerugian, bunga, dan biaya-biaya yang timbul setelah adanya keputusan pengadilan yang telah berkekuatan hukum tetap, notaris tersebut dapat dinyatakan Pailit (Darus, M. L. H. 2017). 
Sedangakan dalam aspek pidannya notaris juga dapat dipidana tentang tanggungjawab Notaris yang melanggar ketentuan dalam peraturan perundang-undangan tidak diatur dalam Undang-Undang Jabatan Notaris. Hal itu bukanlah berarti Notaris tidak dapat dijatuhi sanksi pidana atas kesalahan yang telah dilakukannya. Notaris tetap diberikan sanksi pidana jika terbukti telah melakukan tindak pidana dalam melaksanakan jabatannya. Secara umum terdapat beberapa tindak pidana yang sering dilakukan notaris dalam menjalankan jabatannya, antara lain sebagai berikut (Novita, C. 2018) :

1. Tindak pidana tentang pemalsuan surat sebagaimana yang terdapat dalam Pasal 263 ayat (1), (2) dan Pasal 246, 266 KUHP.

2. Tindak pidana tentang penggelapan sebagaimana yang terdapat dalam Pasal 372 KUHP.

3. Tindak pidana tentang penipuan sebagaimana yang terdapat dalam Pasal 378 KUHP

Pengkualifikasian tindak pidana yang tersebut di atas berkaitan dengan aspek-aspek (Habib Adjie, 2009) :

1. Kepastian hari, tanggal, bulan, tahun, dan pukul menghadap;

2. Pihak (siapa-orang) yang menghadap notaris;

3. Tanda tangan yang menghadap;

4. Salinan akta tidak sesuai dengan minuta akta;

5. Salinan akta ada, tanpa dibuat minuta akta;

6. Minuta akta tidak ditandatangani secara lengkap, tapi minuta akta dikeluarkan;

7. Ada pengurangan atau penambahan angka, kata atau kalimat pada minuta akta yang merugikan pihak lain; dan

8. Ada dugaan notaris melakukan pemunduran tanggal akta yang merugikan pihak lain.

Hal ini dapat dijadikan dasar untuk menjatuhkan sanksi pidana terhadap Notaris, dengan alasan Notaris telah melakukan tindak pidana berupa penipuan dan memalsukan akta. Akta yang telah dibuat oleh notaris apabila memuat unsur dalam tindak pidana, menimbulkan kerugian yang diderita bagi para pihak maupun pihak lain, serta berdasarkan bukti-bukti permulaan yang cukup, maka notaris patut diduga telah melakukan atau turut serta dalam melakukan atau membantu melakukan suatu tindak pidana berkaitan dengan kewenangan notaris berdasarkan Pasal 15 UndangUndang Nomor 30 Tahun 2004 tentang Jabatan Notaris sebagaimana yang telah diubah dengan Undang-Undang Nomor 2 Tahun 2014 (Darus, M. L. H. 2017). 


\section{KESIMPULAN}

Penerapan prinsip kehati-hatian yang dilakukan oleh Notaris dalam proses pembuatan akta otentik yaitu, melakukan pengenalan terhadap identitas penghadap, memverifikasi secara cermat data subyek dan obyek penghadap, memberi tenggang waktu dalam pengerjaan akta, bertindak hati-hati, cermat dan teliti dalam proses pengerjaan akta, memenuhi segala syarat teknik pembuatan akta, Penandatanganan akta dan pembubuhan jempol. Penerapan prinsip kehati-hatian seperti ini sudah seharusnya wajib dilaksanakan notaris agar nantinya notaris dapat mencegah timbulnya permasalahan hukum terhadap akta otentik yang dibuatnya dikemudian hari. Akibat hukum terhadap akta notaris yang dibuat berdasarkan surat palsu dan keterangan palsu adalah batal demi hukum (nitiegbaarheid) sesuai Pasal 1320 ayat (4) dan Pasal 1335 KUHPerdata dan akta yang dibuat kekuatan pembuktiannya terdegradasi dari akta otentik menjadi akta dibawah tangan, akan tetapi tentang kebenaran formal yang terdapat dalam kepala dan penutup akta tersebut tetap mengikat para pihak yang membuatnya.

\section{SARAN}

Diharapkan kepada lembaga legislatif yaitu DPR agar memperjelas kembali pengaturan dalam Pasal 16 ayat (1) huruf a Undang-Undang Jabatan Notaris Perubahannya UUJNP tentang kewajiban Notaris untuk bertindak seksama dalam proses pembuatan akta, agar nantinya Notaris dalam proses pembuatan akta memiliki pedoman dan tuntunan untuk mencegah timbulnya permasalahan hukum dalam akta yang dibuatnya dikemudian hari. Serta pemerintah menyediakan fasilitas teknologi yang dapat digunakan Notaris untuk memastikan keaslian identitas, penyesuaian data antara data yang ada di KTP dengan data yang ada di Dinas Catatan Sipil Discapil terhadap melalui Komputer atau Handphone dan diharapkan notaris dalam proses dan menerima permintaan pembuatan akta lebih berhati-hati, cermat dan teliti menerapkan aturan hukum yang akan dituangkan dalam akta, serta notaries lebih dahulu dapat memberikan legal advice (penyuluhan hukum) oleh penghadap sesuai ilmu kenotariatan yang dimilikinya, agar akta yang dibuatnya sesuai dengan aturan hukum yang berlaku dan tidak bertentangan dengan peraturan perundang-undangan. Notaris sudah seharusnya mencari kebenaran materil terhadap para penghadap. Supaya akta yang dibuat tidak menjadi akta yang menjadi bermasalah dan merugikan para penghadap dikemudian hari.

\section{DAFTAR PUSTAKA}

Afifah, K. (2017). Tanggung Jawab dan Perlindungan Hukum bagi Notaris secara Perdata Terhadap Akta yang Dibuatnya. Lex Renaissance, 2(1), 10.

M. Luthfan Hadi Darus. (2017). Hukum Notariat dan Tanggungjawab Jabatan Notaris. UII Press : Yogyakarta;

Manuaba, P., Bagus, I., Parsa, I. W., Ariawan, K., \& Gusti, I. (2018). Prinsip kehati-hatian notaris dalam membuat akta autentik. Acta Comitas, 3.

Muhammad, Prof. Abdulkadir. (2004). Hukum dan Penelitian Hukum. Bandung: PT. Citra Aditya Bakti 
Novita, C. (2018). Tanggung Jawab Notaris Yang Telah Werda Dan Perlindungan Hukum Terhadap Werda Notaris Atas Akta Yang Dibuat Oleh Atau Dihadapannya Sebelum Werda (Master's thesis, Universitas Islam Indonesia).

Prabowo, T. S. (2017). Tanggung Jawab Calon Notaris Yang Sedang Magang Terhadap Kerahasiaan Akta. Jurnal Repertorium, 4(2).

Rahman, Fikri Ariesta. 2018. Penerapan Prinsip Kehati-Hatian Notaris Dalam Mengenal Para Penghadap. Universitas Islam Indonesia

R Soesanto. (2008).Tugas, Kewajiban, dan Hak-Hak Notaris, Wakil Notaris (Sementara). Pradnya Paramita : Jakarta;

Sodiq, M. (2016). Relevansi Kewajiban Ingkar Notaris dalam Menjalankan Jabatannya (Analisis Pasal 16 Huruff Undang-Undang Nomor 2 Tahun 2014 tentang Perubahan Atas Undang-Undang Nomor 30 Tahun 2004 tentang Jabatan Notaris)(Doctoral dissertation, Universitas Islam Indonesia)

Tunggal, H. S. (2008). Himpunan Peraturan Pelaksanaan Undang-Undang Jabatan Notaris Dilengkapi Putusan Mahkamah Konstitusi \& Ad, Art dan Kode Etik Notaris. Jakarta: Harvarindo

Tim Spektakuler. (2018). Ikatan Pejabat Pembuat Akta Tanah. Rumah Nyaman PPAT. Jakarta: PT Warta Mandiri Multi Media

Tjukup, Ketut, dkk. (2016). Akta Notaris (Akta Otentik) Sebagai Alat Bukti dalam Peristiwa Hukum Perdata. Acta Comitas (2016) 2 : 180 - 188 ISSN : 2502-8960 I eISSN : 2502-7573 